\title{
Alimentação e escravidão no vale do rio Cauca, Nova Granada, através dos olhos de romancistas e viajantes (1750-1851)
}

\section{Food and slavery in the Cauca River Valley, New Granada, through the eyes of novelists and travelers (1750-1851)}

O presente trabalho pretende abordar o uso da literatura, principalmente romances costumbristas do século XIX e relatos de viajantes estrangeiros do mesmo período, como fonte histórica para a análise das práticas alimentares dos escravizados da região do vale do rio Cauca, na Nova Granada, durante os anos de 1750 - última etapa do comércio negreiro - até 1851 - o fim da escravidão. Já o historiador da alimentação Henrique Carneiro, no seu texto As fontes para os estudos históricos sobre a alimentação (2005), prestou atenção na dificuldade que essa área da história tem quanto à pouca quantidade de documentos oficiais úteis para a compreensão dos fenômenos alimentares. Porém, o pesquisador faz um chamado para o uso de múltiplos tipos de fontes, dos quais os relatos de viagens, crônicas e romances sobressaem.

Portanto, no decorrer desta pesquisa tem sido importante prestar especial atenção às metodologias necessárias para o uso da literatura como fonte histórica, assim, temos nos aproximado às teorias produzidas principalmente pela História Cultural, que propõem que para analisar esse tipo de fonte é necessário entender que o que é escrito pelos romancistas e viajantes são representações da realidade e, portanto, como escreveu o historiador José da Silva Horta no seu texto "Nações", marcadores identitários e complexidades da representação étnica nas escritas portuguesas de viagem: Guiné do Cabo Verde (séculos XVI XXVII), publicado em 2013, essas representações provinham de uma "grelha cultural" de que dispunham os europeus para representar, no nosso caso, os escravizados e libertos, sendo o conceito de representação fundamental para entender os métodos para o análise da literatura desde uma perspectiva histórica.

Assim, este trabalho é uma tentativa de compreender o complexo contexto de contato cultural produto da colonização es panhola nas Américas e o comércio transatlântico de pessoas originárias de diferentes partes da África Ocidental, através das suas práticas alimentares: utensílios, alimentos e preparações, representadas por esses romancistas e viajantes.

Finalmente, os romances aqui usados são María de Jorge Isaacs (1867) e El alférez real de Eustaquio Palacios (1886), ademais dos relatos de viajantes de diferentes nacionalidades como o frei espanhol Juan de Santa Certrudis, que viajou à Nova Granada entre 1757 e 1767, o coronel britânico John Potter Hamilton, que esteve na década de 20 do século XIX, e o botânico estadunidense Isaac Holton, que passou pelo vale do Cauca no ano de 1851.

Palavras-chave: história da alimentação; literatura; escravidão; Nova Granada; 1750-1851.

Keywords: food history; literature; slavery; New Cranada; 1750-1851. 